Т.В. Дьяченко ${ }^{1}$, канд. тех. наук, О.О. Колесник ${ }^{2}$

Одеська національна академія харчових технологій, вул. Дворянська, 1/3, г. Одеса, 65082, Україна

e-mail: ${ }^{1}$ victory04@yandex.ru, ${ }^{2}$ kolesnik-sasha12@ukr.net

ORCID: ${ }^{1}$ http://orcid.org/0000-0001-9275-187X; ${ }^{2}$ http://orcid.org/0000-0002-4407-359X

\title{
АЕРОГЕЛЬ - ПЕРСПЕКТИВНИЙ МАТЕРІАЛ ДЛЯ ВИГОТОВЛЕННЯ ІЗОЛЯЦІЇ ЄМНОСТЕЙ ДЛЯ ТРАНСПОРТУВАННЯ ЗРІДЖЕНОГО ПРИРОДНОГО ГАЗУ
}

\begin{abstract}
Робота присвячена дослідженню різних типів ізоляції, які використовують в процесі виготовлення танків для метановозів. Розроблена методика розрахунків та проведені розрахункові дослідження добової випаровуваності та металоємності для n'яти типів ізоляиії: порошково-вакуумної; екрано-вакуумної; пінополеуретану; піноскла та аерогелю. Аналіз результатів показав, шзо аерогель є перспективним видом теплової ізоляиії для використання в кріогенних ємностях для транспортування зрідженого природного газу.

Ключові слова: Зріджений природний газ - Теплова ізоляція - Танкер - Метановоз - Добова випаровуваність - Металоємність
\end{abstract}

\section{1. ВСТУП}

Зріджений природний газ (ЗПГ) є перспективним для використання в якості альтернативного палива у важкодоступних регіонах, де будівництво трубопроводів неможливе чи не рентабельне. Використання ЗПГ дуже ефективно для вирішення проблем постачання газу при нерівномірному газоспоживанні, для зняття пікових навантажень.

Перспективність зрідженого природного газу базується на можливості його трансконтинентальних перевезень за допомогою крупнотонажних кріогенних танкерів, а також по суші в залізничних та автомобільних цистернах. За прогнозами провідних організацій [1-4] попит на природний газ (ПГ) буде стабільно зростати до 2030 р. (рис. 1). Наприклад, Японія за останні 30 років задовольняє $100 \%$ своїх потреб в газі за рахунок зрідженого природного газу [5]. Сьогодні біля $23 \%$ природного газу транспортується морським шляхом в якості ЗПГ [6].

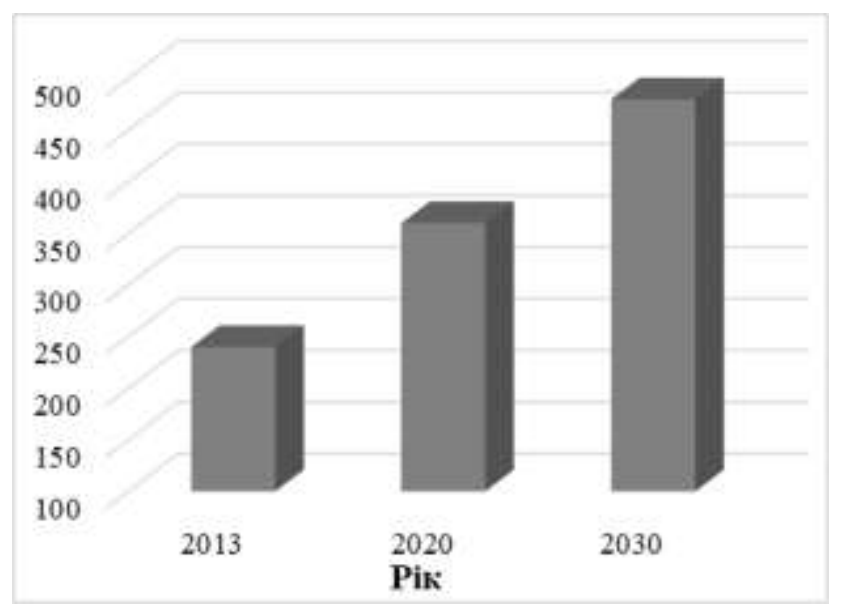

Рис. 1. Прогнози для споживання ЗПГ у світі [7], млн. тон на рік

В останні десятиліття технологічний розвиток промисловості орієнтовано на реалізацію заходів, спрямованих на економію енергетичних ресурсів $\mathrm{i}$ зниження антропогенного навантаження на навколишнє середовище. Надійність теплової ізоляції є одні- єю $з$ проблем при транспортуванні на далекі відстані. Якісна ізоляція значно зменшує втрати від випаровування цінних продуктів та за рахунок цього рівень забруднення навколишнього середовища. Крім того, безконтрольне випаровування газу під час перевезення неприпустимо за правилами техніки безпеки.

Робота присвячена дослідженню різних видів теплової ізоляції та пошуку іiї нових видів, які дозволять значно зменшити об'єми викидів природного газу в атмосферу Землі при його транспортуванні.

\section{2. ГАЛУЗІ ЗАСТОСУВАННЯ ПРИРОДНОГО ГАЗУ}

Природний газ відноситься до корисних копалин та утворюється в надрах землі при повільному анаеробному (без доступу повітря) розкладанні органічних речовин - у вигляді окремих скупчень (газові поклади) або у вигляді газової шапки нафтогазових родовищ, або в розчиненому стані в нафті або воді; часто $\epsilon$ попутним газом при видобутку нафти; у пластових умовах (умовах залягання в земних надрах) знаходиться в газоподібному стані; існує також у вигляді природних газогідратів в океанах і зонах вічної мерзлоти материків.

Природний газ являє собою природну суміш газоподібних вуглеводнів, у складі якої переважає метан $(80 \ldots 98 \%)$, але в них зустрічаються також сірководень, азот, вуглекислота, водяні пари. ПГ не отруйний, проте при концентрації метану в повітрі більше $10 \%$ можлива ядуха внаслідок зменшення кількості кисню в повітрі та він становить значну пожежну небезпеку.

Природний газ $є$ перспективним в якості пального, яке згодом замінить інші види палив. Він має найменший рівень шкідливих викидів (рис. 2) [3] та створює низьке шумове забруднення двигунів [8]. Стиснутий метан (20...25 МПа) коштує в два рази дешевше бензину, подовжує ресурс двигуна. При спалюванні ПГ утворюється тільки вода і вуглекислий газ, у той час як при спалюванні нафтопродуктів $\mathrm{i}$ вугілля утворюються ще кіптява і зола. Крім того, 
емісія парникового вуглекислого газу при спалюванні природного газу найнижча, за що він отримав назву «зелене паливо» (рис. 3).

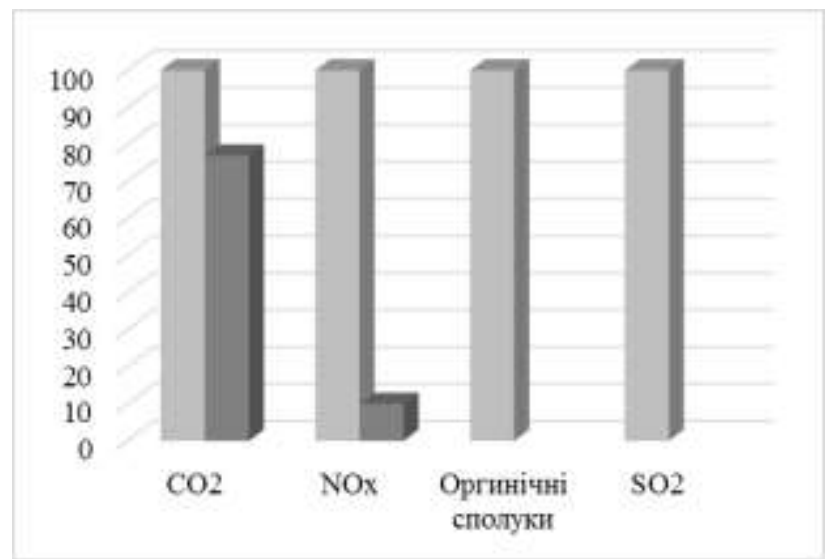

Рис. 2. Відсоткове співввідношення викидів при використанні дизильного палива $\square$ та ЗПГ $\square$ [9]

У світі близько половини поставок газу припадає на енергетичні компанії і комунальне господарство. Навіть якщо в будинку немає газової плити або газового водонагрівача, все одно світло і гаряча вода, швидше за все, отримані з використанням ПГ.

3 природного газу можливо виробляти рідкі моторні палива за технологією gas-to-liquid (GTL) [Ошибка! Источник ссылки не найден.]. Вперше рідкі вуглеводні з синтез-газу отримали німецькі хіміки Франц Фішер і Ганс Тропш ще в 1923 році.

Для хімічної промисловості за схемою, схожою на процес Фішера-Тропша, з природного газу отримують метанол $\left(\mathrm{CH}_{3} \mathrm{OH}\right)$. Він використовується як реагент для боротьби 3 гідратними пробками, які утворюються в трубопроводах при низьких темпера- турах. Метанол в свою чергу є сировиною для виробництва більш складних хімічних речовин: формальдегіду, ізоляційних матеріалів, лаків, фарб, клеїв, присадок для палива, оцтової кислоти та пластмас.

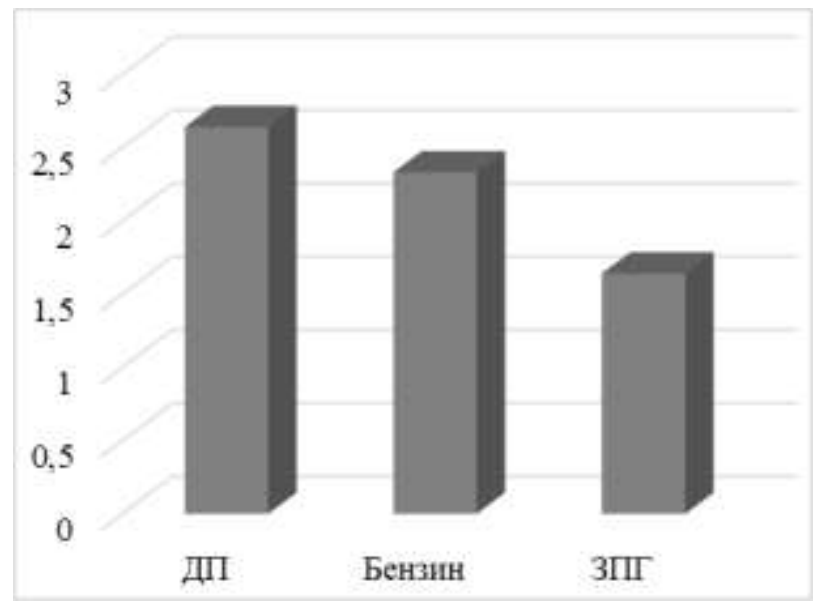

Рис. 3. Середня кількість викидів $\mathrm{CO}_{2}$,

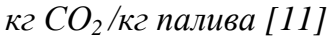

Шляхом декількох хімічних перетворень $з$ природного газу отримують також мінеральні добрива. На першій стадії це аміак, який сам по собі є добривом.

Аміак - гарний холодоагент. Він використовується в промислових установках, а також в якості сировини для виробництва азотовмісних сполук: азотної кислоти, аміачної селітри, карбаміду. Ціаністий водень, що також отримується з аміаку, разом з ацетиленом служить вихідною сировиною для виробництва синтетичних волокон.

\section{3. ВИДИ ТАНКЕРІВ ТА ІЗОЛЯЦІЙНИХ МАТЕРІАЛІВ ДЛЯ ТРАНСПОРТУВАННЯ ЗПГ}

Усі судна-газовози можна розділити на три основні групи (рис. 4) в залежності від тиску і температури вантажів, які суднові системи можуть підтримувати у вантажних танках в процесі перевезення:

- напірного типу (без охолодження вантажу);

- полу-напірного типу (з частковим охолодженням вантажу);

- рефрижераторного типу (з повним охолодженням вантажу, коли тиск насичених парів близький до атмосферного).

За останні 50 років було випущено більш ніж видів 170 танкерів. Вкладні танки мають різноманітну форму, включаючи сферичну, циліндричну та призматичну $[5,12]$. На рис. 5 зображений розподіл світового флоту танкерів ЗПГ за даними 2011 року [6]. Теплова ізоляція $є$ запорукою економічно оптимальних умов транспортування кріогенних рідин та має забезпечувати втрати ЗПГ не більше 0,1 \%/доба [3].

В суднобудуванні в якості ізоляції використовується ряд матеріалів [13]:

- тверді, які можуть витримувати значні навантаження і грають роль підтримки танків в корпусі судна. Це деякі породи дерева (бальса, азоб) або ж пластики з високою щільністю. Всі ці матеріали повинні витримувати навантаження, які зазнає танк при термальних впливах;

- еластичні, такі як мінеральна вата або пористі пластики низької щільності. Еластичні матеріали наносяться на поверхню танка за допомогою способів, які забезпечують надійне кріплення ізоляції до поверхні танка або ж до вторинного бар'єра;

• у вигляді порошку (наприклад, перліт). При використанні порошкових матеріалів весь простір навколо танка має бути заповнено ізоляційним матеріалом. Матеріали такого типу дуже часто використовуються для ізоляції танків на суднах, що перевозять кріогенну рідину (зріджений природний газ) під атмосферним тиском.

В результаті розвитку технологій з'являються нові та вдосконалені типи ізоляційних матеріалів. Одним $з$ таких $є$ аерогелі - це гелі, в яких рідка фаза повністю заміщена газоподібною. Такі матеріали мають рекордно низьку щільністю і демонструють ряд унікальних властивостей: твердість, прозорість, жароміцність, надзвичайно низьку теплопровідність і т.п. Поширені аерогелі на основі аморфного діоксиду кременя, глинозему, а також оксидів хрому та олова. 
На початку 1990-х отримані перші зразки аерогелю на основі вуглецю.

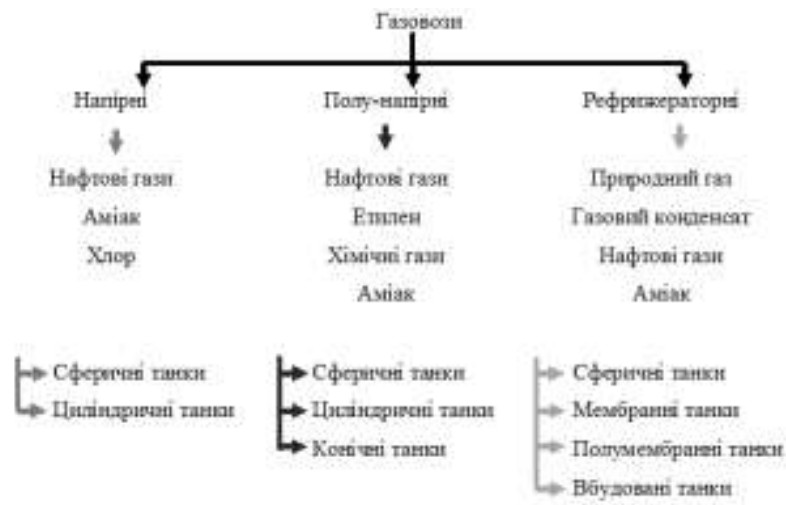

Рис. 4. Типи газовозів [13]

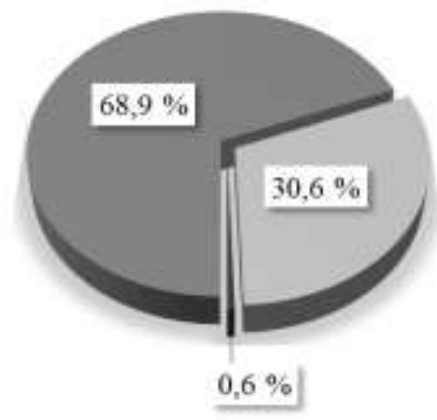

Рис. 5. Розподіл світового флоту танкерів ЗПГ за типами вантажних систем [6]

$\square$-мембранні; $\square$-сферичні; $\square$ - інші

Аерогель - ізоляційний матеріал майбутнього. Сьогодні його випробовують в якості матеріалу для космічних костюмів для позбавленні болю у спині космонавтів, які з'являються в наслідок довгострокового перебування у невагомості [14-16].
Аерогелі відносяться до класу мезопористих матеріалів, у яких порожнини займають не менше 50 \%, а як правило, 90-99 \% обсягу, а щільність стано-

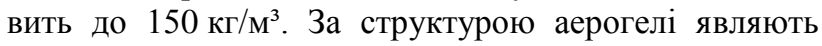
собою деревоподібну мережу з об'єднаних в кластери наночастинок розміром 2-5 нм і пор розмірами до 15 нм (рис. 6).
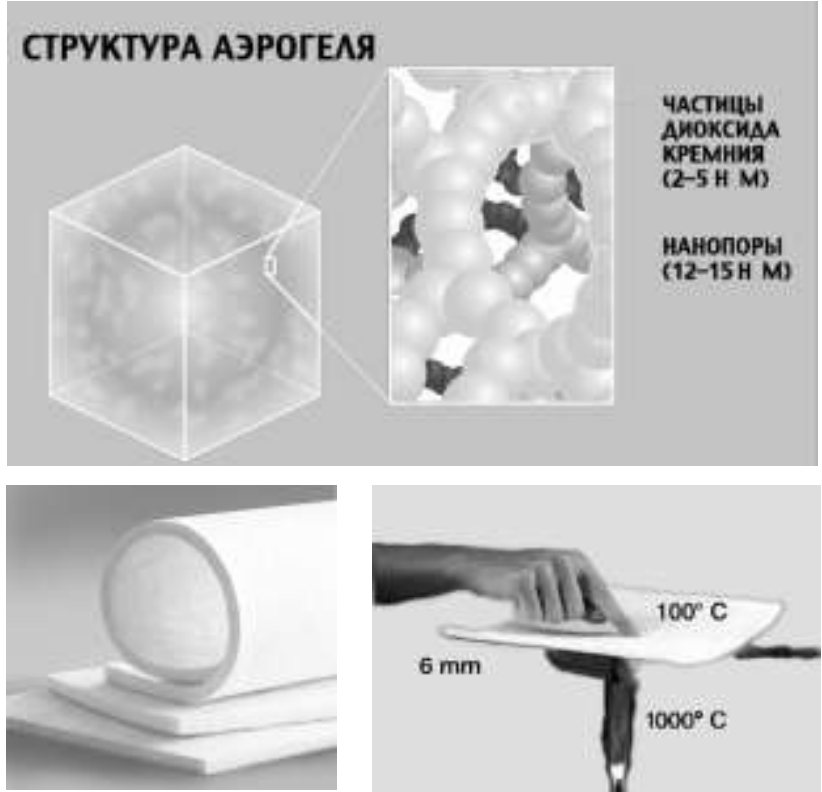

Рис. 6. Аерогель: а-структура; б-зовнішній вигляд; в - основна властивість аерогелю - висока ізоляційна якість при малій товщчині

В промисловості використовують три типи аерогелів: на базі силікагелів, вуглеводнів і оксидів металів. Найчастіше в експериментах використовують перший тип [17].

\section{4. ВИПАРОВУВАНІСТЬ І МЕТАЛОСМНІСТЬ ТАНКІВ В ЗАЛЕЖНОСТІ ВІД ТИПУ ІЗОЛЯЦЇ̈}

В процесі досліджень були розглянуті три типи рефрижераторних танкерів: сферичні, циліндричні та призматичні $[5,12]$ для загального об'єму рідкого метану у ємностях $V=130000 \mathrm{~m}^{3}$ (табл. 1). Розроблена методика розрахунку відсотка випаровування метану на добу та металоємність танків для п'яти типів

Таблиияя 1. Вихідні дані для розрахунку

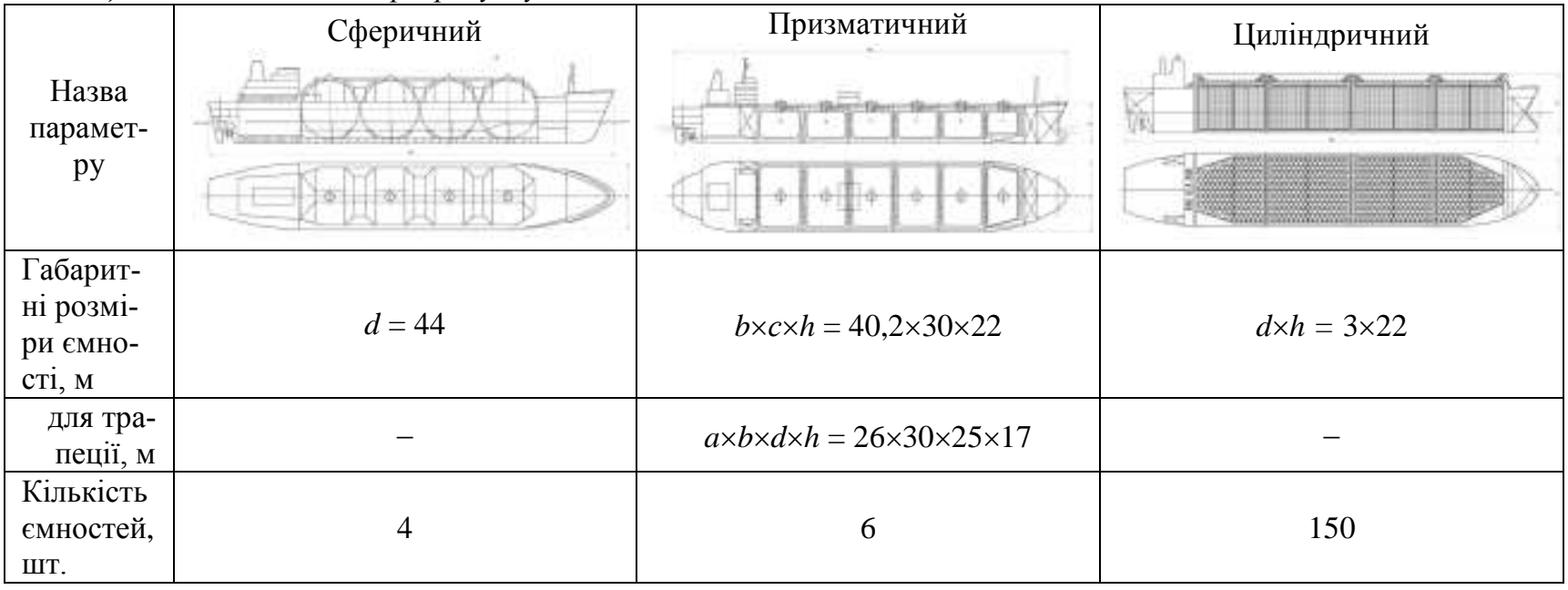


ізоляцій: розрахунку відсотка випаровування метану на добу та металоємність танків для п'яти типів ізоляцій: порошково-вакуумна; екрано-вакуумна; пінополеуретан; піноскло та аерогель (табл. 2).
Попередні розрахунки показали, що завдяки особливості конструкції циліндричних ємкостей коефіцієнт випаровування у них найменший серед інших типів танків, але металоємність значно вища. Тому циліндричні ємкості далі не розглядали.

Табличя 2. Характеристики ізолящзійних матеріалів [20-25]

\begin{tabular}{|l|c|c|c|c|c|}
\hline \multicolumn{1}{|c|}{ Назва параметру } & $\begin{array}{c}\text { Екрано- } \\
\text { вакуумна }\end{array}$ & Аерогель & $\begin{array}{c}\text { Порошково- } \\
\text { вакуумна (перлі- } \\
\text { тно-вакуумна) }\end{array}$ & $\begin{array}{c}\text { Пінопо- } \\
\text { ліуретан }\end{array}$ & Піноскло \\
\hline Щільність, кг/м ${ }^{3}$ & $300 \ldots 700$ & $30 \ldots 150$ & $75 \ldots 150$ & $26 \ldots 300$ & $110 \ldots 200$ \\
\hline $\begin{array}{l}\text { Коефіцієнт теплопровідності, } \\
\text { Вт/(м·К) }\end{array}$ & - & $0,017 \ldots 0,019$ & 0,0177 & $0,019 \ldots 0,035$ & $0,04 \ldots 0,08$ \\
\hline $\begin{array}{l}\text { Коефіцієнт теплового випро- } \\
\text { мінювання екранів }\end{array}$ & 0,04 & - & - & - & - \\
\hline
\end{tabular}

Аналіз результатів для трьох видів танків та товщини ізоляції 200 мм (рисунки 7 і 8) дозволив визначити, що для екрано-вакуумної ізоляції добові втрати цінного метану найменші, але аерогелієва ізоляція має найнижчу вагу за рахунок невеликої густи-

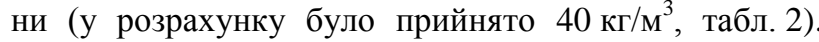
Однак, у екрано-вакуумної ізоляції є один вагомий недолік - складність якісної конструкції при створені танків великих розмірів.

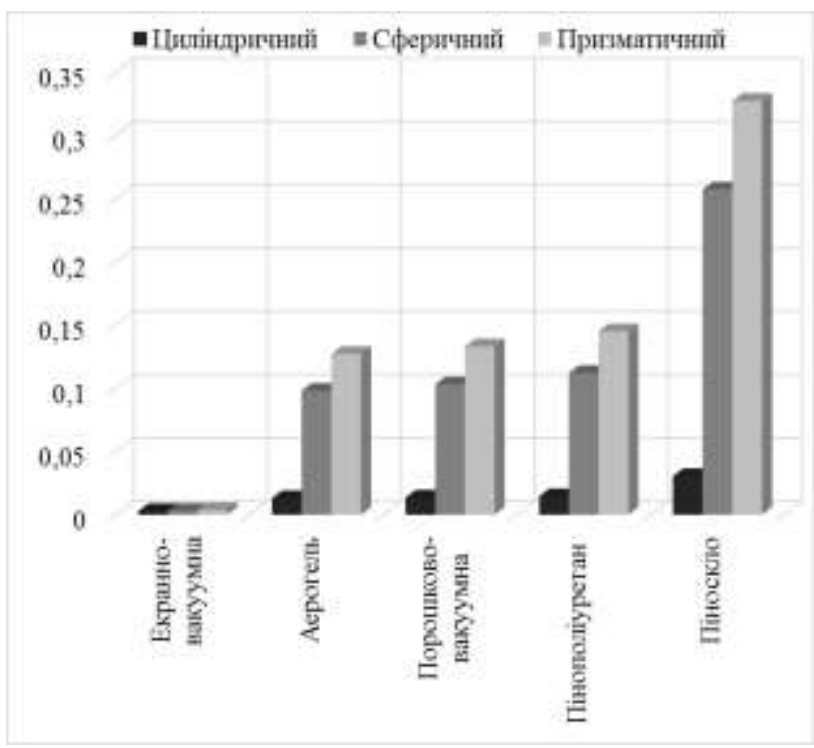

Рис. 7. Добове випаровуваність метану в \% (товщчина ізоляції 200 мм)

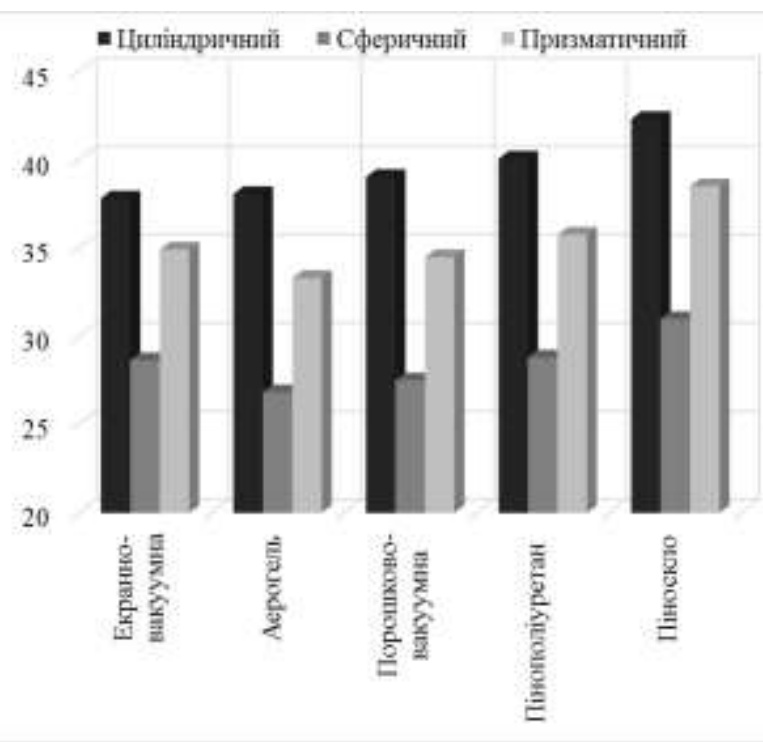

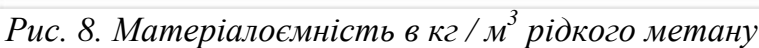
(товщина ізоляиії 200 мм)

Третє місце за обома показниками посідає класична порошково-вакуумна ізоляція. Порівняння її 3 аерогелем показує деякі переваги аерогелю: відсутня необхідність створювати вакуум у ізоляційному просторі; при порушенні цілісності оболонки ємності до 90 \% пор аерогелю залишаються закритими. При цьому ефективний коефіцієнт теплопровідності аерогелю збільшується незначно, тоді як для порошково-вакуумної ізоляції коефіцієнт теплопровідності збільшується у 4 рази.

Пінополіуретан дещо гірший, ніж порошково-вакуумна ізоляція. Піноскло є найгіршою ізоляцією за всіма показниками.

Дослідження вартості різних типів ізоляції показують, що вартість порошкової ізоляції найнижча. Тому перлітовий пісок - один з найбільш затребуваних матеріалів, які використовуються в криогенній техніці. Інші види значно дорожчі. Наприклад, піноскло дорожче в 5...8 разів. Вартість аерогелю в даний час близька до вартості екранно-вакуумної ізоляції. Однак нові розробки, які були проведені в Китаї, показали, що масове виробництво цієї ізоляції дозволить значно знизити його ціну [24]. В перспективі аерогель зможе повністю замінити перліт в виробництві кріогенних ємностей.

\section{5. ВИСНОВКИ}

Використання зрідженого природного газу базується на можливості його перевезень на значні відстані. Для цього використовують крупнотонажні кріогенні танкери, які обладнані низькотемпературною теплоізоля- 
цією. Дослідження різних видів ізоляції та пошук нових їі видів показали, що аерогель $є$ перспективним типом ізоляції ємностей для перевезення ЗПГ.

Масове виробництво аерогелю значно знизить його ціну, та в перспективі повністю замінить перліт в виробництві кріогенних ємкостей. Це дозволить до $2 \%$ зменшити об'єми викидів природного газу в атмосферу Землі при його транспортуванні та на 2,5...3,5 \% зменшити масу танків, що в цілому знизить витрати на транспортування корисного вантажу.

\section{ЛИТЕРАТУРА}

1. Рачевский Б.С. Сжиженные углеводородные газы. - М.: Изд-во «НЕФТЬ и ГАЗ», 2009. - 640 с.

2. Ананенков А.Г. Сжиженный природный газ: некоторые оценки и перспективы // Газовая промышленность. Спецвыпуск «Производство, транспортировка, хранение и использование сжиженного природного газа». - 2011. - № 668. - С. 2-3.

3. Басарыгин М.Ю., Грешняков М.И. Организация работ в области производства и морской транспортировки сжиженного природного газа в ОАО «Газпром»// Газовая промышленность. Спецвыпуск «Производство, транспортировка, хранение и использование сжиженного природного газа». - 2011. № 668. - С. 28-40.

4. [Електронний ресурс]. Режим доступу: https://yearbook.enerdata.ru/natural-gas-consumption-in-theworld.html.

5. Лавренченко Г.К., Копытнин А.В. Криогенные комплексы производства и отгрузи СПГ, его приема, хранения и регазификации в системе международной торговли // Технические газы. - 2010. - № 3. C. 2-19.

6. Воробьев А.М. Мировой флот танкеров СПГ в условиях современного рынка природного газа // Газовая промышленность. Спецвыпуск «Производство, транспортировка, хранение и использование сжиженного природного газа». - 2011. - № 668. - С. 41-43.

7. [Електронний ресурс]. Режим доступу: http://www.vestifinance.ru/infographics/3400.

8. Толочкин О.Ю. Использование СПГ в качестве моторного топлива // Газовая промышленность. Спецвыпуск «Производство, транспортировка, хранение и использование сжиженного природного газа». - 2011. - № 668. - С. 77-78.

9. Николаева М.В. СПГ как судовое топливо // Газовая промышленность. Спецвыпуск «Производство, транспортировка, хранение и использование сжиженного природного газа». - 2011. - № 668. - С. 64-65.

10. МакИнтош С. Эндрю, Ноубл Г. Питер, Роквелл Джим, Рамлахан Д. Карл. Морской транспорт природного газа // Нефтегазовое обозрение. - 2008. - С. 58-66.

11. [Електронний ресурс]. Режим доступу: http://www.krone-trailer.com/pycский/kompanija/filosofija-iehkologichnost/racionalnoe-ispolzovanie-ehnergii/raspredelenie-ehmissii-co2.

12. Усюкин И.П. Техника низких температур. Атлас. - М.: Пищевая промышленность, 1977. - 244 с.

13. Баскаков С.П. Перевозка сжиженных газов морем. - СПб.: Судостроение, 2001. - 272 с.

14. [Електронний ресурс]. Режим доступу: http://hi-news.ru/space/kosmonavtov-odenut-v-oblegayushhiekostyumy.html.

15. [Електронний ресурс]. Режим доступу: http://hi-news.ru/space/predstavlen-legkij-i-udobnyj-skafandrkosmicheskogo-turista.html.

16. [Електронний ресурс]. Режим доступу: http://tayga.info/news/2015/07/23/ 122440.

17. Скоренко Т. Когда воздух кажется тяжелым // Популярная механика. - 2013. - № 6. - С. 20-26.

18. [Електронний ресурс]. Режим доступу: https://ru.wikipedia.org/wiki/

19. [Електронний ресурс]. Режим доступу: https://www.unitednuclear.com.

20. Шумилин Н. Экранно-вакуумная изоляция - настоящее и будущее криогенной техники // Gasworld. 2015. - Вып. 43. - С. 38-40.

21. [Електронний ресурс]. Режим доступу: http://bankpatentov.ru/node/474028.

22. [Електронний ресурс]. Режим доступу: https://ru.wikipedia.org/wiki/\%D0\%90\%D1\%8D\%D1\%80\%D0\%BE\%D0\%B3\%D0\%B5\%D0\%BB\%D1\%8C.

23. Справочник по физико-техническим основам криогеники / Под ред. М.П. Малкова. - М.: Энергоатомиздат, 1985. - 431 с.

24. [Електронний ресурс]. Режим доступу: http://srbu.ru/stroitelnye-materialy/81-penopoliuretanaharakteristiki.html\#p3.

25. [Електронний ресурс]. Режим доступу: https://ru.wikipedia.org/wiki/\%D0\%9F\%D0\%B5\%D0\%BD\%D0\%BE\%D1\%81\%D1\%82\%D0\%B5\%D0\%BA $\% \mathrm{D} 0 \% \mathrm{BB} \% \mathrm{D} 0 \% \mathrm{BE}$.

T.V. Diachenko ${ }^{1}$, Candidate of Technical Sciences, A.O. Kolesnik ${ }^{2}$

Odessa National Academy of Food Technologies, 1/3, Dvoryanska Str., Odessa, 65082, Ukraine

e-mail: ${ }^{1}$ victory04@yandex.ru, ${ }^{2}$ kolesnik-sasha12@ukr.net

ORCID: ${ }^{1}$ http://orcid.org/0000-0001-9275-187X; ${ }^{2}$ http://orcid.org/0000-0002-4407-359X 


\section{AEROGEL IS PERSPECTIV MATERIAL FOR LIQUID NATURAL GAS TRANSPORT VESSEL ISOLATION PRODUCTION}

Work is devoted to research of isolation different types which apply in the production course of tankers to methane carriers. The calculations technique is developed and settlement researches of a daily evaporability and metal consumption for five types of isolation are conducted: the powder and vacuum; the screen and vacuum; the polyurethane foam; the glass foam and the aerogel. The analysis of reultat showed that the aerogel is a perspective view of thermal isolation for use in cryogenic capacities for transportation of the liquefied natural gas.

Key words: Liquefied natural gas - Thermal insulation - Tanker - Methane Carrier - Daily evaporation - Metall Consumption

\section{REFERENCES}

1. Rogachevsky B.V. 2009. The Liquefied Hydrocarbonic Gases // Moscow: Izd-vo “Neft' i Gaz”. - 640 p. (in Russian)

2. Ananenkov A.G. 2011. The Liquefied Natural Gas: Some Estimates and Prospects // Gazovaya Promishlennost'. Spetsialny Vipusk "Proizvodstvo, transportirovka, khranenie I ispolzovanie sgizennogo prirodnogo gaza". - No. 668. - P. 2-3. (in Russian)

3. Basarigin M. Yu., Greshnyakov M.I. 2011. The Works Organization in the Field of Production and Sea Transportation of the Liquefied Natural Gas in Gazprom JSC // Gazovaya Promishlennost'. Spetsialny Vipusk "Proizvodstvo, transportirovka, khranenie I ispolzovanie sgizennogo prirodnogo gaza". - No. 668. - P. 28-40. (in Russian)

4. [Electronic source]. Access: https://yearbook.enerdata.ru/natural-gas-consumption-in-the-world.html.

5. Lavrenchenko G.K., Kopytin A.V. 2010. Cryogenic Complex of LNG Production and Uploading, its Acceptance, Storage and Regasification in the International Trade System // Tekhnicheskie Gazy [Industrial Gases]. - No. 3. - P. 2-19. (in Russian)

6. Vorobyev A.M. 2011. World Fleet of the LNG Tankers in the Conditions of the Modern Market of Natural Gas // Gazovaya Promishlennost'. Spetsialny Vipusk "Proizvodstvo, transportirovka, khranenie I ispolzovanie sgizennogo prirodnogo gaza". - No. 668. - P. 41-43. (in Russian)

7. [Electronic source]. Access: http://www.vestifinance.ru/infographics/3400.

8. Tolochkin O.Yu. 2011. Use of LNG as Motor Fuel // Gazovaya Promishlennost'. Spetsialny Vipusk "Proizvodstvo, transportirovka, khranenie I ispolzovanie sgizennogo prirodnogo gaza". - No. 668. - P. 77-78. (in Russian)

9. Nikolaeva M.V. 2011. LNG as Ship Fuel // Gazovaya Promishlennost'. Spetsialny Vipusk "Proizvodstvo, transportirovka, khranenie I ispolzovanie sgizennogo prirodnogo gaza". - No. 668. - P. 64-65. (in Russian)

10. MacIntosh S. Anrue, Nouble G. Piter, Rokvell Jim, Ramlahan D. Karl. 2008. Sea Transport of Natural Gas // Neftegazovoe obozrenie. - P. 58-66. (in Russian)

11. [Electronic source]. Access: http://www.krone-trailer.com/pyсcкий/kompanija/filosofija-iehkologichnost/racionalnoe-ispolzovanie-ehnergii/raspredelenie-ehmissii-co2.

12. Usukin I.P. 1977. Equipment of Low Temperatures. Atlas. - Moscow: Pischevaya promishlennost'. - 244 p. (in Russian)

13. Baskakov S.P. 2001. Transportation of the Liquefied Gases by the Sea. - Sant-Peterburg.: Sudistroenie. -272 p. (in Russian)

14. [Electronic source]. Access: http://hi-news.ru/space/kosmonavtov-odenut-v-oblegayushhie-kostyumy.html.

15. [Electronic source]. Access: http://hi-news.ru/space/predstavlen-legkij-i-udobnyj-skafandr-kosmicheskogoturista.html.

16. [Electronic source]. Access: http://tayga.info/news/2015/07/23/ 122440.

17. Skorenko T. 2013. When Air Seems Heavy // Populyarnaya mekhanika. - No. 6. - P. 20-26. (in Russian)

18. [Electronic source]. Access: https://ru.wikipedia.org/wiki.

19. [Electronic source]. Access: https://www.unitednuclear.com.

20. Shumilin N. 2015. Screen and Vacuum Isolation - the Present and the Future of Cryogenic Equipment// Gasworld. - Vol. 43. - P. 38-40. (in Russian)

21. [Electronic source]. Access: http://bankpatentov.ru/node/474028.

22. [Electronic source].

Access: https://ru.wikipedia.org/wiki/\%D0\%90\%D1\%8D\%D1\%80\%D0\%BE\%D0\%B3\%D0\%B5\%D0\%BB\%D1\%8C.

23. Handbook of Physical and Technical Fundamentals of Cryogenics. 1985. Ed. M.P. Malkov. - Moscow: Energoatomizdat. - 431 p. (in Russian)

24. [Electronic source]. Access: http://srbu.ru/stroitelnye-materialy/81-penopoliuretana-harakteristiki.html\#p3.

25. [Electronic source].

Access: https://ru.wikipedia.org/wiki/\%D0\%9F\%D0\%B5\%D0\%BD\%D0\%BE\%D1\%81\%D1\%82\%D0\%B5\%D0\%BA\% D0\%BB\%D0\%BE. 